Scholedge International Journal of

Management \& Development

ISSN 2394-3378, Vol.05, Issue 09 (2018)

Pg 96-113.

DOI: 10.19085/journal.sijmd050901
Published by: Scholedge Publishing www.theSCHOLEDGE.org

Email: editorial@thescholedge.org

(C) Publisher

\title{
The Role of Sovereign Wealth Funds in Promoting the External Stability of the Home Economy
}

\author{
Osama El-Baz \\ Economist, Asharqia Chamber of Commerce and Industry, Saudi Arabia.
}

\begin{abstract}
Sovereign Wealth Funds (SWFs) are currently playing an important role in the global economy. We investigated the role of SWFs in promoting the external stability of the home economy using a data set spanning 106 countries over the period (1997-2015), whereby Arellano- Bond dynamic panel data models were employed to assess the treatment effect of SWFs on both the level of the current account balance and its volatility. Empirical results revealed that SWFs can play an important role in smoothing the management of the current account balance in the long run. Nonetheless, commodity-based SWFs are expected to outperform non-commodity based SWFs in this respect. Our policy recommendation is that emerging economies should consider the establishment of SWFs to enhance the external stability of their home economies, allocating privatization proceeds to these investment vehicles to protect the rights of future generations in benefiting from them rather than directing such proceeds to finance current government expenditure and budget deficit. Finally, attention should be paid to the implementation of the generally accepted principles and practices when establishing SWFs to ensure their ability to function properly.
\end{abstract}

Keywords: Sovereign Wealth Funds (SWFs), External Balance, Dynamic Panel, Policy.

\section{1- Introduction:}

Sovereign Wealth Funds (SWFs) are state-owned investment vehicles that invest globally in various types of assets. SWFs are currently playing an important role in both the MENA region and the global economy as their assets are estimated at over US\$7 trillion in June 2017, meanwhile, the GCC funds hold around 38.8 percent of these assets (SWFI).

SWFs are financed from the resources of the state which are either commodity or non-commodity based. Sources of finance include a balance of payments surpluses, official foreign currency operations, the proceeds of privatizations of state-owned enterprises, fiscal surpluses, and/or receipts resulting from commodity exports (IWG, 2008, p.27).

SWFs are a heterogeneous group of institutional investment that could have different policy purposes, There are five main types of SWFs: (i) stabilization funds, where the primary objective is to insulate the government budget and the economy against the volatility of commodity prices. Their investment horizons and liquidity management focus on the conduct of countercyclical fiscal policies to smooth boom/bust cycles. That's why they tend to invest mainly in highly liquid assets such as fixed income securities; (ii) savings funds, play an important role in achieving intergeneration justice and protecting the rights of future generations in benefiting from the economy's unrenewable resources through the conversion of these assets into a diversified portfolio of assets and mitigate the effects of the Dutch disease. Their investment mandate targets high risk-return profile, thus, allocating high portfolio shares to equities; (iii) reserve investment corporations, whose assets are often still counted as reserve assets, and are established to increase the rate of return on international reserves. Their investment strategy focuses on higher returns by high allocations in equities and alternative investments; (iv) development funds, which play a vital role in funding socio-economic projects or promoting industrial policies that might raise a country's potential output growth; and (v) contingent pension reserve funds, are set up to meet identified future outflows with respect to 
pension-related contingent-type liabilities on the government's balance sheet. They invest in equities and other investments to offset rising pension costs (Al-Hassan et al, 2013, pp.5-6).

The IMF (2008) confirmed that SWFs have potential effects on at least four areas of interest: (i) Fiscal Policy, SWFs can facilitate fiscal stabilization and the saving of fiscal resources for long-term purposes. Also, they can introduce comprehensive investment and risk management frameworks and enhance the transparency and accountability in the public management of financial assets; (ii) Monetary Policy, the activities of SWFs could have repercussions on the exchange rate as investment abroad followed by the repatriation of returns involves currency transactions. If SWFs have discretion over whether they invest domestically or abroad, then decisions over investments will require careful coordination with the monetary authorities. Otherwise, a sizeable shift from foreign into domestic assets would pose difficulties for the monetary authorities' sterilization operations; (iii) Public Sector Balance Sheet Implications, SWFs provide better management of the public-sector balance sheet. Hence, the asset management strategy of the SWF should be consistent with an economy's underlying macro-fiscal objectives, while taking into account associated risks; (iv) External Stability, SWFs may have important implications for the assessment of the economy's external stability both in the current and capital account, which is relevant for both the surveillance of countries with SWFs and for countries that receive large SWF inflows. Commodity exporting economies may run transitory current account surpluses during the period in which the resources are being extracted and exported, and to draw down assets after the resources have been exhausted. Meanwhile, countries that receive SWF inflows are likely to be affected in terms of the capital and financial account, and relative prices, and accordingly external stability may be affected.

It is noteworthy that SWFs are not a new phenomenon in the global economy as the beginning of their inception dates back to the pre-1970s. However, around 67.1 percent of them have been established within the period (20002015) (Figure 1). The vast majority of SWFs are commodity based, as shown in Figure (2), around 56.6 percent of them are commodity based. As for the geographical distribution of SWFs, they are highly concentrated in both the Middle East and Asia regions, respectively (Figure 3).

Figure (1): Breakdown of Sovereign Wealth Funds by Year of Establishment

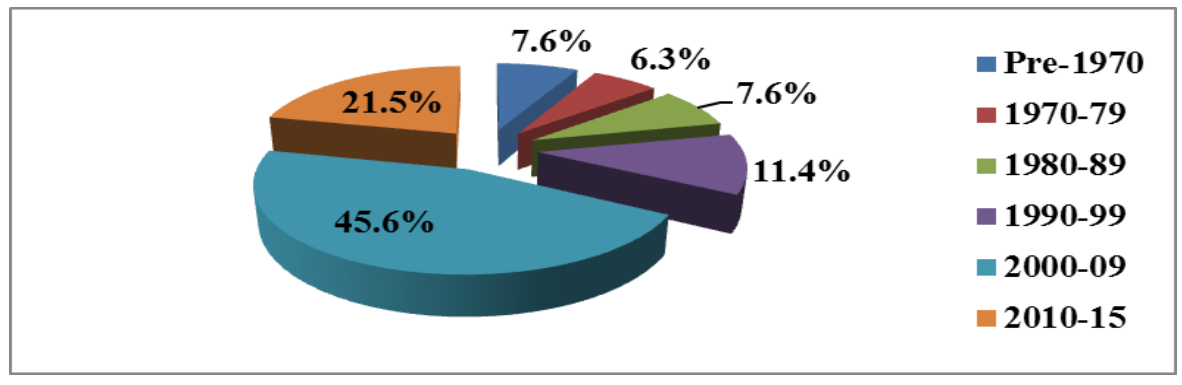

Source: Sovereign Wealth Fund Institute.

Figure (2): SWFs by Type and Origin of Funds in 2015

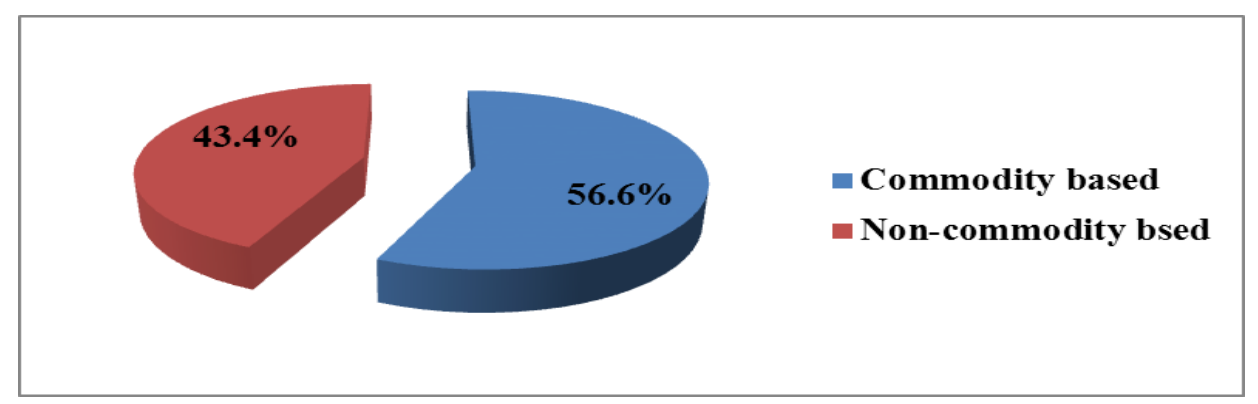

Source: Sovereign Wealth Fund Institute. 
Figure (3): Geographical Distribution of Sovereign Wealth Funds by Region

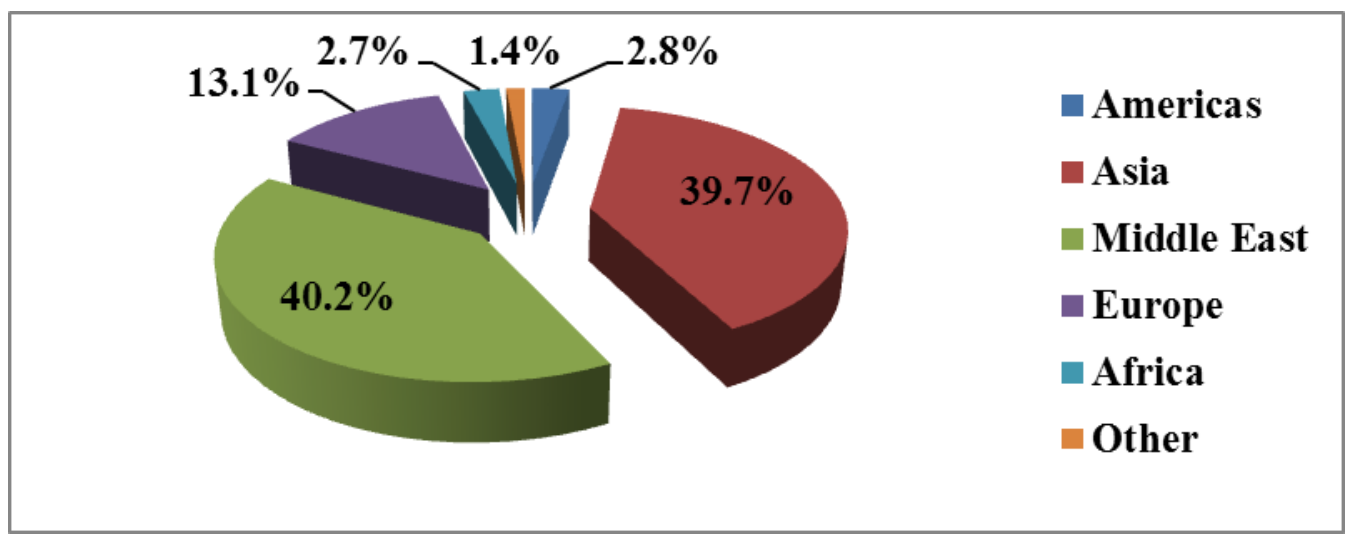

Source: Sovereign Wealth Fund Institute.

Empirical studies have investigated the role of sovereign wealth funds in promoting fiscal stability. Fasano (2000) investigated whether stabilization funds have contributed to enhancing the effectiveness of fiscal policy in selected countries. He concluded that funds have made budget expenditures less driven by revenues availability in Kuwait, Norway and the State of Alaska.

Other empirical studies have tried to understand the role of SWFs in reducing the volatility of public expenditure, Sugawara (2014) used a panel data set of 68 resource-rich countries to test this hypothesis, the findings confirmed lower volatility in countries that have stabilization funds. Coutinho et al. (2013) studied the experience of around 80 resource-rich economies and argued that SWFs tend to dampen the pro-cyclicality of government consumption more than fiscal rules. Koh (2016) confirmed that fiscal policy becomes more counter-cyclical after the establishment of oil funds and that these funds are typically associated with smoother government consumption. Finally, Mohaddes and Raissi (2017) concluded that having an SWF can mitigate the negative growth effects of commodity price volatility, especially in countries that enjoy higher-quality institutions.

To the best of our knowledge, no empirical studies have investigated the role of SWFs in promoting the external stability of the acquirer economy, so this paper will fill this gap in the literature by employing econometric techniques to test this hypothesis.

The rest of the paper is organized as follows: Section Two: SWFs and the Economy's External Stability: introduces the conceptual framework behind both internal and external balance as well as the role of SWFs in promoting the economy's external stability. Section Three: Econometric Analysis: introduces the data and variables used in the empirical analysis, econometric methodology and key results. Section Four: Conclusion and Policy Implications: includes the main findings of empirical analysis and policy implications.

\section{2- SWFs and the Economy's External Stability:}

SWFs can enhance the macroeconomic management of large current account surpluses. By transferring excess public revenues into investment funds, hence alleviating potential inflationary pressures triggered by capital inflows that place upward pressure on nominal exchange rates, which could result in a real exchange rate appreciation and the deterioration of the external competitiveness of domestic exports and an increase imports.

By investing capital inflows offshore, SWF states can maintain a stable exchange rate in the face of large shocks. However, offshoring capital inflows may become unsustainable or suboptimal, especially when perpetuated indefinitely (Gomes, 2008, p. 6).

In open economies, policymakers are motivated by achieving both the internal and external balance for the economy. Internal balance requires the full employment of a country's resources and domestic price level stability. On the other hand, the external balance could be attained when a country's current account is neither too deeply in deficit nor too strongly in surplus. 
The government can use a number of policies to influence employment and the balance of payments. These policies can be classified as (i) Expenditure-changing policies, which affect the balance of payments primarily by changing domestic income and aggregate demand through fiscal and monetary policies; (ii) Expenditure-Switching Policies, target switching expenditure towards domestic goods through changes in the exchange rate. Currency depreciation switches spending by both domestics and foreigners from foreign goods to domestic goods and so increases net exports; (iii) Direct controls, including tariffs, quotas, and restrictions on the flow of goods and capital. These are also expenditure-switching policies, but they can be aimed at specific balance-of-payments items and could be used to stem domestic inflation when other policies fail.

The Swan Diagram in Figure (4) demonstrates how expenditure-switching and expenditure-changing policies can be used to achieve simultaneous internal and external balance. The XX line in Figure (4) is positively sloped and shows different combinations of exchange rates and domestic absorption that result in external balance. On the other hand, line II is negatively sloped and shows various combinations of exchange rates and domestic absorption that result in internal balance, or full employment with no inflation. Hence, the intersection of the XX and II curves defines the possible combinations of external and internal imbalance and helps in deciding the policy mix required to reach internal and external balance simultaneously.

The external balance is achieved at point (1). In this case, an increase in expenditures will increase income and imports and results in a deficit in the balance of payments. The elimination of this deficit requires depreciation of domestic currency to promote the competitiveness of exports and reduce imports. Note that any point to the right of the XX line indicates an external deficit, and any point to the left indicates an external surplus.

Then the appreciation of domestic currency will lead to an increase in imports and reduce exports, hence causing unemployment. In order to restore full employment, domestic expenditures must be increased.Note that any point to the left of II line indicates underemployment and any point to the right of this line indicates inflation (Krugman and Obstfeld, 2003). The four zones highlighted in figure (4) are called "zones of Economic Discomfort" as at each one of them either the internal or the external balance of the economy is sacrificed.

It is also known that many economies are running either pegged or managed float exchange rate regimes. The Mundell-Fleming model shows how a nation can use both fiscal and monetary policies to maintain both internal and external balance without any change in the exchange rate. In the Mundell-Fleming model, in figure (5), the IS curve is negatively sloped because lower rates of interest (and higher investments) are associated with higher incomes and higher savings and imports for the quantities of goods and services demanded. The LM curve is positively sloped because higher incomes mean a higher demand for money which must be associated with higher interest rates to maintain equilibrium in the money market. The BP curve is also positively sloped because higher incomes and imports require higher rates of interest to attract capital inflows and maintain the balance-of-payments in equilibrium. All markets are in equilibrium at point (E) where the IS, LM, and BP curves intersect together. Starting from point (E) where internal and external balances are reached, the nation can reach full- employment at a higher level of national income along with external balance by pursuing an expansionary fiscal policy that shifts the IS curve to the right to IS ${ }^{\prime}$ and a contractionary monetary policy that shifts the LM curve to the left to $\mathrm{LM}^{\prime}$, while holding the exchange rate fixed. In this case, all markets will be in equilibrium at point (F). 
Figure (4): Internal Versus External Balance and the "Four Zones of Economic Discomfort"

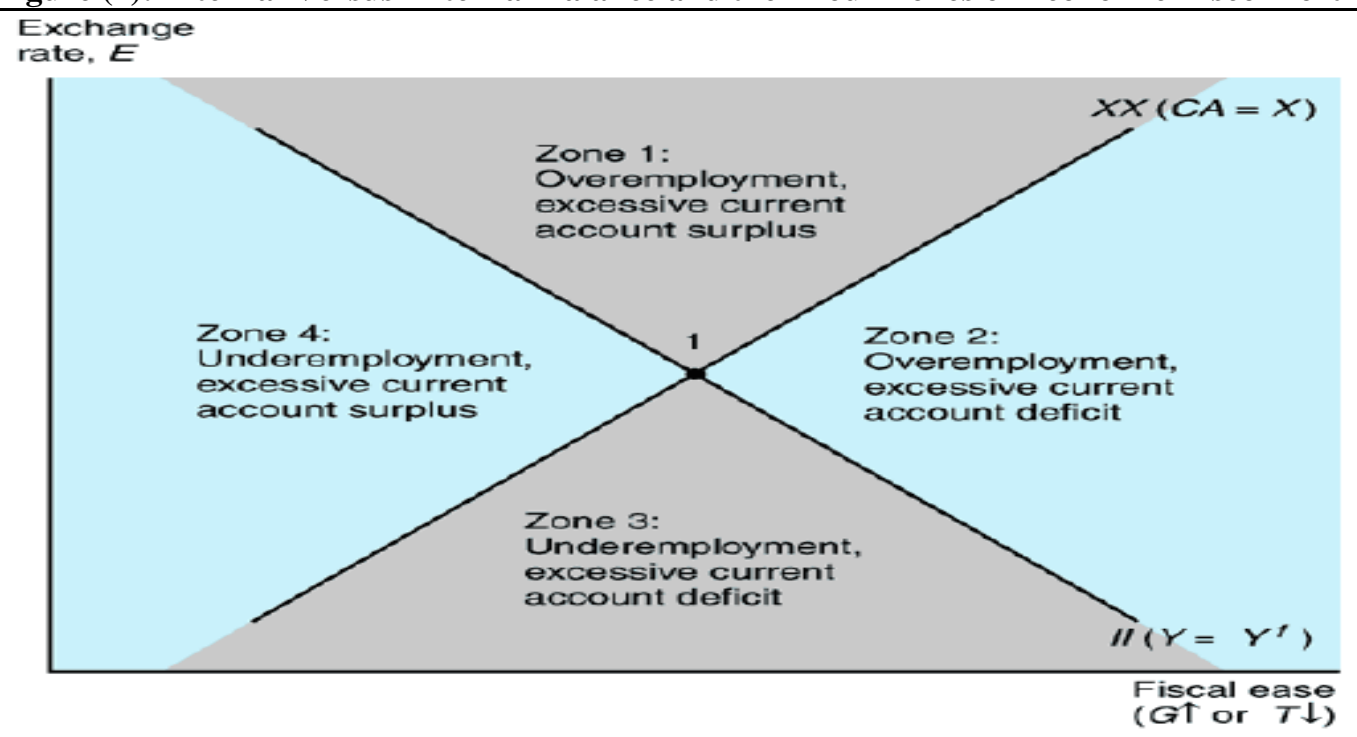

Source: Krugman, P. and Obstfeld, M., 2003, “The International Monetary System, 1870-197”.

Chapter 18, International Economics: Theory and Policy, Sixth Edition.

Figure (5): Internal and External Balance of the Economy Under the Mundell-Fleming Model

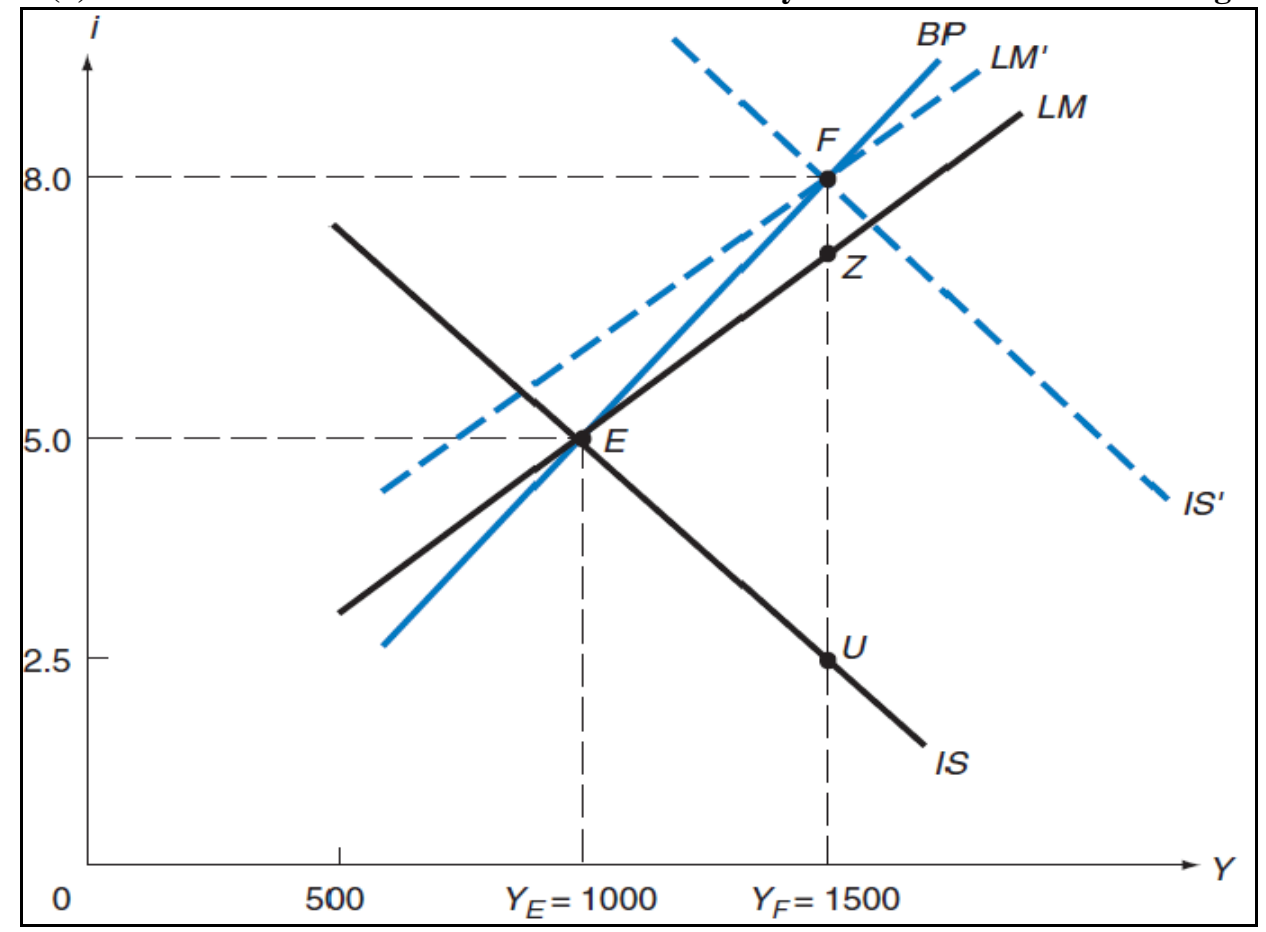

Source: Salvatore, D, 1999,“Open-Economy Macroeconomics: Adjustment Policies”, Chapter 18. International Economics, Sixth Edition.

A proper assessment of the current account sustainability is becoming an increasingly important issue for policymakers. Dynamic macroeconomic models have been extensively used in the literature to analyze current account developments, especially in the medium and long-term. For example, Debelle and Faruqee (1996) empirically studied the 'structural' determinants of current account balances for advanced countries from a saving- 
investment perspective. Chinn and Prasad (2003) and Lee et al (2008) extended the analysis to include emerging market countries, adding some further specifications to the model.

As for recent empirical studies, Clausen and Kandil (2005) investigated cyclical fluctuations in the current and financial accounts of the balance of payments and major underlying components for nine industrial countries. They confirmed the importance of fluctuations in output growth to the cyclicality of the current and financial account balances. The necessary and sufficient condition to sustain a large current account deficit is high domestic growth, which tends to stimulate financial inflows and provides adequate resources for financing. Morsy (2009) examined the main underlying determinants of the medium-term current account balance for oil-exporting countries using dynamic panel estimation techniques, and results revealed that the fiscal balance, oil balance, oil wealth, age dependency, and the degree of maturity in oil production matter in determining the equilibrium current account in case of oil-exporting economies. Clower and Ito (2012) examined the determinants of various degrees of current account persistence; they found that the type of exchange rate regimes no longer affects the extent of current account persistence. However, countries with greater trade or financial openness, or those with mounting pressure from real exchange rate misalignment tend to have a smaller degree of current account persistence while international reserves holding seems to contribute to a larger degree of persistence.

\section{3- Econometric Analysis:}

\section{3-1- Data and Variables:}

We compiled a data set spanning 106 countries over the period (1997-2015) (the country list is in the annex in the table (2)). Data on years of inception of SWFs were obtained from the Sovereign Wealth Funds Institute (SWFI). The SWF variable will be included in our regression models as a zero-one dummy variable.

The dependent variables in our models are the current account balance-to-GDP ratio and the volatility of the current account is measured as a three-year rolling window variation coefficient of the current account balance-to- GDP ratio. Other explanatory variables will be included in the models to account for the effect of macroeconomic variables that could affect the current account. These variables are: trade openness, output gap, fiscal balance, inflation rate, financial openness index (Chinn- Ito Index), age dependency ratio, real effective exchange rate (REER), world oil prices, world food prices, resource rent cycle, government revenue instability, GDP per capita growth rate, export concentration index and a GCC dummy variable. Variable definitions and data sources are mentioned in details in the table (1) in the annex.

\section{3-2- Methodology:}

Arellano- Bond dynamic panel data models will be used to assess the treatment effect of SWFs on both the level of the current account balance and its volatility in countries that have established such investment vehicles, then we will test whether this effect differs for both commodity and non-commodity based SWFs. The models used will have the following form:
$\mathrm{CA}_{\mathrm{i}, \mathrm{t}}=\alpha \mathrm{CA}_{\mathrm{i}, \mathrm{t}-1}+\mathrm{SWF}_{\mathrm{i}, \mathrm{t}} \boldsymbol{\beta}_{+} \mathbf{X}_{\mathrm{i}, \mathrm{t}}^{\prime} \gamma+\mathrm{u}_{\mathrm{i}, \mathrm{t}}$
Equation (1)

Where, the dependent variable will be either the current account balance-to-GDP ratio or the volatility of the current account which is measured as a three-year rolling window variation coefficient of the current account balance-toGDP ratio. The terms on the right-hand side of the equation are the lagged values of the dependent variable to capture persistency episodes in the current account balance, a zero-one dummy variable for SWFs, and a set of explanatory variables.

In the model specification, the lagged regress and included in the right-hand side is endogenous to the fixed effects in the error term. OLS and fixed affects estimates for such specifications will suffer from dynamic panel bias as demonstrated in Nickell (1981). That's why the difference GMM estimator outlined in Arellano \& Bond (1991) is the commonly used method to circumvent this endogeneity problem, where the first difference transformation expunges fixed effects, and higher lags of the endogenous regressors are used as internal instruments. It is noteworthy that, in unbalanced panels, this transformation may cause large data loss and so the forward orthogonal 
deviations transformation of Arellano \& Bover (1995) is more commonly used. Furthermore, Blundell \& Bond (1998) find that if the regress and has high persistence ( $\alpha$ has an absolute value close to 1 ) then difference GMM estimators perform poorly as the regress and behaves like a random walk and that past values will be uninformative about future changes. In the latter case, the system GMM estimator developed by Arellano \& Bover (1995) and Blundell \& Bond (1998) will be preferable.

The Arellano-Bond test checks for the existence of serial correlation in the residuals by testing the residuals in the differenced equations for serial correlation. It is expected to find evidence for first-order serial correlation, so we test for second-order serial correlation in the differenced residuals. One needs to be unable to reject the null hypothesis of no second-order serial correlation.

A three-step procedure will be employed in this paper to circumvent the concern that SWFs may not be truly exogenous in our models. While one would expect that the set-up of SWFs would induce better management of the current account balance, it might be possible that they have been set up after an economy has already improved its external balances. If there is reverse causality, the estimation of the impact of SWFs on the current account balance will be biased and the estimator will be inconsistent.

We will use a three-step procedure following (Elbadawi, Soto and Youssef, 2018, p. 13), where: (i) In the first stage, we will estimate a probit model of the determinants of having a $S W F_{i t}$ in place and compute the predicted probability $S W F$ Predicted $i t$; (ii) In the second stage, we regress $S W F_{i t}$ on the predicted probabilities obtained from the first stage and a set of instruments $\left(z_{i t}\right)$ and compute the fitted values $S W F F_{i t t e d}$; (iii) In the third stage, we regress the current account balance $\left(y_{i t}\right)$ on both the fitted values obtained from the second stage and a set of regressors $\left(x_{i t}\right)$.

\section{3-3- Empirical Results:}

\section{3-3-1- Unit Root Tests:}

We tested for the stationarity properties of our panel dataset to ensure that there is no evidence of non-stationarity. The majority of unit root tests for panel data that are widely used in the empirical literature assume a balanced panel dataset (Levin, Lin, and Chu, 2002; and Im, Pesaran, and Shin, 2003). However, our panel dataset is unbalanced, so we used the Fisher-type unit root test which is suitable for unbalanced panel datasets. The results showed that there is no evidence for non-stationarity in our panel dataset.

\section{3-3-2- Results:}

In order to analyze the effect of SWFs on the current account balance and its volatility, we used the three-step procedure mentioned in the methodology. The first and Second stages of this approach were conducted using probit models. Table (1) reports the results of estimating a random effects probit regression of the incidence of SWFs that have been used to calculate the predicted probabilities of having an SWF, results confirmed that resource-rich economies, as well as countries with concentrated exports, are more likely to implement SWFs, also the GCC economies are more likely to prefer establishing these institutions.

Then, the predicted probabilities of having an SWF in place for each year over the period (1997-2015) have been used, conditional on the observed values of fundamentals, which have been used as an instrument in the regression model represented by table (2), hence efficiency is achieved when the SWF dummy is filtered against the fundamentals and the instrument obtained in the first step.

Table (1): Random Effects Probit Estimation

\begin{tabular}{|c|c|}
\hline Dependent Variable: SWF & Coefficient \\
\hline Resource Rent Cycle & $0.0559224^{*}$ \\
\hline Revenue Instability & 0.0241963 \\
\hline Inflation & -0.0026767 \\
\hline Economic Development & $-0.0672442 * * *$ \\
\hline Export Concentration & $3.948895^{* * *}$ \\
\hline GCC & $12.85226 * * *$ \\
\hline Constant & $-7.944996^{* * *}$ \\
\hline
\end{tabular}

Notes: Symbols $* * *, * *$, and $*$ denote significance at $1 \%, 5 \%$, and $10 \%$ levels, respectively. 
Table (2): Linear Filtering Model

\begin{tabular}{|c|c|}
\hline Dependent Variable: SWF & Coefficient \\
\hline Resource Rent Cycle & 0.0097586 \\
\hline Revenue Instability & 0.0849545 \\
\hline Inflation & -0.0001505 \\
\hline Economic Development & -0.0047718 \\
\hline Export Concentration & 0.1257323 \\
\hline GCC & 0.3481487 \\
\hline SWF Predicted & $0.1347439 * * *$ \\
\hline
\end{tabular}

Notes: Symbols $* * *, * *$, and $*$ denote significance at $1 \%, 5 \%$, and $10 \%$ levels, respectively.

In order to analyze the effect of SWFs on the current account balance, the fitted values (SWFFitted) calculated after running the regression model presented by the table (2) have been used as an instrument to run the Arellano- Bond dynamic panel regression model represented by the table (3) hereunder. Results confirmed the idea that SWFs can play an important role in the smoothing the management of the current account balance in the long run as represented by the positive and highly statistically significant coefficient on the (SWFFitted) variable, also current account balances for the countries considered are persistent as expected as shown by the coefficient on the lagged dependent variable. Both the business cycle "GDP gap" and world oil prices can have a positive effect on the current account balance which is expected for oil exporting economies. On the other hand, openness to trade, real exchange rate appreciation, and world food prices are expected to have a negative effect on the current account balance in the long run, which is intuitive.

Table (3): The Determinants of the Current Account Balance

\begin{tabular}{|c|c|}
\hline Dependent Variable: CA & Coefficient \\
\hline CA(-1) & $0.5986319 * * *$ \\
\hline Trade Openness & $-0.0634047 * *$ \\
\hline GDP Gap & $0.152773 * * *$ \\
\hline Inflation & -0.0232958 \\
\hline Fiscal Balance & 0.0088096 \\
\hline Financial Openness & -0.3633621 \\
\hline Age Dependency Ratio & -0.04989 \\
\hline Log (REER) & $-40.60967 * * *$ \\
\hline World Oil Price & $0.0463426 * *$ \\
\hline World Food Prices & $-0.0494708 * * *$ \\
\hline SWFFitted & $30.54718 * * *$ \\
\hline Observations & 1418 \\
\hline Countries & 104 \\
\hline Instruments & 162 \\
\hline Arellano Bond Serial Correlation Test AR(2) & 0.9052 \\
\hline
\end{tabular}

Notes: Symbols $* * *, * *$, and $*$ denote significance at $1 \%, 5 \%$, and $10 \%$ levels, respectively. Robust standard errors were used. The dependent variable is the current account balance-toGDP ratio.

In order to analyze the effect of SWFs on the current account volatility "instability", the fitted values (SWFFitted) calculated after running the regression model presented by the table (2) have been used as an instrument to run the Arellano- Bond dynamic panel regression model represented by the table (4) hereunder. Empirical results confirmed that SWFs can play a crucial role in promoting the stability of the current account balance in the long run as shown by the negative and highly statistically significant coefficient on the (SWFFitted) variable, especially as 
instability episodes in the current account balances seemed to be persistent to some extent as represented by the coefficient on the lagged dependent variable. Moreover, positive output gaps are expected to curb the volatility of the current account balance through the expansion of exports. On the other hand, both openness to trade and real exchange rate appreciation could exacerbate the volatility of the current account balance due to their detrimental effect on exports.

Table (4): The Determinants of the Current Account Instability

\begin{tabular}{|c|c|}
\hline Dependent Variable: CAInstability & Coefficient \\
\hline CAInstability (-1) & $0.4104237^{* * *}$ \\
\hline Trade Openness & $0.5412411^{* *}$ \\
\hline GDP Gap & $-0.673535^{* * *}$ \\
\hline Inflation & -0.020733 \\
\hline Fiscal Balance & -0.0150295 \\
\hline Financial Openness & -5.937408 \\
\hline Age Dependency Ratio & -0.9475885 \\
\hline Log (REER) & $112.4661^{* *}$ \\
\hline World Oil Price & -0.1964007 \\
\hline World Food Prices & -0.0015662 \\
\hline SWFFitted & $-314.6806^{*}$ \\
\hline Observations & 1353 \\
\hline Countries & 103 \\
\hline Instruments & 130 \\
\hline Arellano Bond Serial Correlation Test AR(2) (P.value) & 0.2060 \\
\hline
\end{tabular}

Notes: Symbols $* * *, * *$, and $*$ denote significance at $1 \%, 5 \%$, and $10 \%$ levels, respectively. Robust standard errors were used. The dependent variable is a three-year rolling window variation coefficient of the current account balance-to- GDP ratio to proxy for the current account instability.

In order to ensure the robustness of our findings, we decomposed SWFs to commodity and non-commodity based SWFs (the list of SWFs by type is in table " 3 " in the annex) to test whether these institutions can play a vital role in promoting the external stability of the home economy.

The three-step procedure mentioned earlier was used in order to analyze the effect of commodity-based SWFs on the current account balance and its volatility, the first and Second stages of this approach were conducted using probit models. Table (5) reports the results of estimating a random effects probit regression of the incidence of commoditybased SWFs that have been used to calculate the predicted probabilities of having an SWF, results confirmed that countries with concentrated exports are more likely to implement commodity-based SWFs, also the GCC economies are more likely to prefer establishing commodity-based SWFs. Then, we estimated the predicted probabilities of having a commodity-based SWF for each year over the period (1997-2015), conditional on the observed fundamentals, which have been used as an instrument in the regression model represented by the table (6).

Table (5): Random Effects Probit Estimation for Commodity-based SWFs

\begin{tabular}{|c|c|}
\hline Dependent Variable: SWF & Coefficient \\
\hline Resource Rent Cycle & 0.0563386 \\
\hline Revenue Instability & -0.0245895 \\
\hline Inflation & 0.0031137 \\
\hline Economic Development & $-0.0758452^{* *}$ \\
\hline Export Concentration & $2.939871^{* *}$ \\
\hline GCC & $14.35455^{* * *}$ \\
\hline Constant & $-8.396102^{* * *}$ \\
\hline
\end{tabular}

Notes: Symbols $* * *, * *$, and $*$ denote significance at $1 \%, 5 \%$, and $10 \%$ levels, respectively. 
Table (6): Linear Filtering Model

\begin{tabular}{|c|c|}
\hline Dependent Variable: SWF & Coefficient \\
\hline Resource Rent Cycle & 0.0081766 \\
\hline Revenue Instability & 0.1778131 \\
\hline Inflation & -0.0004323 \\
\hline Economic Development & -0.0013453 \\
\hline Export Concentration & -0.0631666 \\
\hline GCC & 0.1313846 \\
\hline SWFPredicted & $0.1715406^{* * *}$ \\
\hline
\end{tabular}

Notes: Symbols $* * *, * *$, and $*$ denote significance at 1\%, 5\%, and $10 \%$ levels, respectively.

In order to analyze the effect of commodity-based SWFs on the current account balance, the fitted values (SWFFitted) calculated after running the regression model represented by the table (6) have been used as an instrument to run the Arellano- Bond dynamic panel regression model represented by the table (7). Results confirmed the idea that commodity-based SWFs can play an important role in the smoothing the management of the current account balance in the long run through the influx of returns on investments abroad, as shown by the positive and highly statistically significant coefficient on the (SWFFitted) variable, also current account balances for the countries considered are persistent as expected as shown by the coefficient on the lagged dependent variable. Both the business cycle "GDP gap" and world oil prices can have a positive effect on the current account balance which is expected for oil exporting economies. On the other hand, openness to trade, real exchange rate appreciation, and world food prices are expected to have a deleterious effect on the current account balance in the long run, which is expected.

Table (7): The Determinants of the Current Account Balance

\begin{tabular}{|c|c|}
\hline Dependent Variable: CA & Coefficient \\
\hline CA(-1) & $0.6067441^{* * *}$ \\
\hline Trade Openness & $-0.0913905 * *$ \\
\hline GDP Gap & $0.1444259^{* *}$ \\
\hline Inflation & -0.0209654 \\
\hline Fiscal Balance & 0.0094838 \\
\hline Financial Openness & -0.5452226 \\
\hline Age Dependency Ratio & -0.0488444 \\
\hline Log (REER) & $-41.65919 * * *$ \\
\hline World Oil Price & $0.0516778 * *$ \\
\hline World Food Prices & $-0.0443546 * * *$ \\
\hline SWFFitted & $37.17237 * *$ \\
\hline Observations & 1193 \\
\hline Countries & 89 \\
\hline Instruments & 162 \\
\hline Arellano Bond Serial Correlation Test AR(2) & 0.8921 \\
\hline
\end{tabular}

Notes: Symbols $* * *, * *$, and $*$ denote significance at $1 \%, 5 \%$, and $10 \%$ levels, respectively. Robust standard errors were used. The dependent variable is the current account balance-to-GDP ratio.

In order to analyze the effect of commodity-based SWFs on the current account volatility "instability", the fitted values (SWFFitted) calculated after running the regression model presented by the table (6) have been used as an instrument to run the Arellano- Bond dynamic panel regression model represented by the table (8). Empirical findings confirmed that commodity-based SWFs can play a crucial role in promoting the stability of the current account balance in the long run as shown by the negative and statistically significant coefficient on the (SWFFitted) 
variable, especially as instability episodes in the current account balances seemed to be persistent to a certain extent as represented by the coefficient on the lagged dependent variable. Moreover, positive output gaps are expected to play a crucial role in curbing the volatility of the current account balance through the expansion of exports. The demographic factors proxied by the age dependency ratio are expected to limit the fluctuations in the current account balance in the long run, which may be because the increase in numbers of economically dependents in the economy is expected to limit consumption and stabilize imports in the long term. On the other hand, real exchange rate appreciation could exacerbate the volatility of the current account balance due to its detrimental effect on the competitiveness of exports.

Table (8): The Determinants of the Current Account Instability

\begin{tabular}{|c|c|}
\hline Dependent Variable: CAInstability & Coefficient \\
\hline CAInstability (-1) & $0.4172139^{* * *}$ \\
\hline Trade Openness & 0.5885507 \\
\hline GDP Gap & $-0.721563^{* * *}$ \\
\hline Inflation & 0.0768364 \\
\hline Fiscal Balance & -0.0152353 \\
\hline Financial Openness & -5.730188 \\
\hline Age Dependency Ratio & $-1.261892^{*}$ \\
\hline Log (REER) & $109.4565^{* *}$ \\
\hline World Oil Price & -0.2373177 \\
\hline World Food Prices & 0.0257164 \\
\hline SWFFitted & $-448.252^{*}$ \\
\hline Observations & 1140 \\
\hline Countries & 88 \\
\hline Instruments & 130 \\
\hline
\end{tabular}

Notes: Symbols $* * *, * *$, and $*$ denote significance at $1 \%, 5 \%$, and $10 \%$ levels, respectively. Robust standard errors were used. The dependent variable is a three-year rolling window variation coefficient of the current account balanceto- GDP ratio to proxy for the current account instability.

In order to proceed further and investigate the effect of non-commodity based SWFs on the current account balance and its volatility, we employed the three-step procedure outlined earlier, whereby the first and Second stages of this approach were conducted using probit models. Table (9) reports the results of estimating a random effects probit regression of the incidence of non-commodity based SWFs that have been used to calculate the predicted probabilities of having a SWF, results confirmed that countries with a concentrated export basket are more likely to implement non-commodity based SWFs. Also, the GCC economies are more likely to prefer establishing noncommodity based SWFs to maximize the return on their fiscal surpluses, which is actually the case for the United Arab Emirates. On the other hand, both inflation and economic development are expected to reduce the likelihood of having an SWF, which may be justified by the tendency of many countries to spend more on health and education sectors as a priority rather than directing funds toward financial investments abroad. Then, we estimated the predicted probabilities of having a non-commodity based SWF for each year over the period (1997-2015), conditional on the observed fundamentals, which have been used as an instrument in the regression model represented by the table (10).

\section{Table (9): Random Effects Probit Estimation for Non-commodity-based SWFs}

\begin{tabular}{|c|c|}
\hline Dependent Variable: SWF & Coefficient \\
\hline Resource Rent Cycle & 0.0388821 \\
\hline Revenue Instability & -1.230254 \\
\hline Inflation & $-0.0969501^{* *}$ \\
\hline Economic Development & $-0.0896668^{* * *}$ \\
\hline Export Concentration & $6.964428^{* * *}$ \\
\hline GCC & $14.89931^{* * *}$ \\
\hline Constant & $-10.15266^{* * *}$ \\
\hline
\end{tabular}

Notes: Symbols $* * *, * *$, and $*$ denote significance at $1 \%, 5 \%$, and $10 \%$ levels, respectively. 
Table (10): Linear Filtering Model

\begin{tabular}{|c|c|}
\hline Dependent Variable: SWF & Coefficient \\
\hline Resource Rent Cycle & 0.0081766 \\
\hline Revenue Instability & 0.1778131 \\
\hline Inflation & -0.0004323 \\
\hline Economic Development & -0.0013453 \\
\hline Export Concentration & -0.0631666 \\
\hline GCC & 0.1313846 \\
\hline SWFPredicted & $0.1715406^{* * *}$ \\
\hline
\end{tabular}

Notes: Symbols $* * *, * *$, and $*$ denote significance at $1 \%, 5 \%$, and $10 \%$ levels, respectively.

The effect of non-commodity based SWFs on the current account balance has been evaluated, the fitted values (SWFFitted) calculated after running the regression model represented by the table (10) have been used as an instrument to run the Arellano- Bond dynamic panel regression model represented by the table (11). Results provided an evidence that non-commodity based SWFs can play an important role in smoothing the management of the current account balance in the long run through the flow of returns on investments abroad which can partially offset any potential deficit in the trade balances for oil exporters in case of low world oil prices, as shown by the positive and statistically significant coefficient on the (SWFFitted) variable, also current account balances for the countries considered are persistent as expected as shown by the coefficient on the lagged dependent variable. Moreover, both openness to trade and real exchange rate appreciation are expected to have a negative effect on the current account balance in the long run, which is expected as the appreciation of domestic currency in real terms will discourage exports and make imports more competitive.

Table (11): The Determinants of the Current Account Balance

\begin{tabular}{|c|c|}
\hline Dependent Variable: CA & Coefficient \\
\hline CA(-1) & $0.6570793^{* * *}$ \\
\hline Trade Openness & $-0.0542173^{* *}$ \\
\hline GDP Gap & 0.019461 \\
\hline Inflation & 0.0478914 \\
\hline Fiscal Balance & -0.0031066 \\
\hline Financial Openness & -0.4053312 \\
\hline Age Dependency Ratio & -0.0245795 \\
\hline Log (REER) & $-17.79754^{* * *}$ \\
\hline World Oil Price & 0.0103904 \\
\hline World Food Prices & -0.0156145 \\
\hline SWFFitted & $31.75103^{*}$ \\
\hline Observations & 1285 \\
\hline Countries & 91 \\
\hline Instruments & 162 \\
\hline Arellano Bond Serial Correlation Test AR(2) & 0.6120 \\
\hline (P.value) & \\
\hline
\end{tabular}

Notes: Symbols $* * *, * *$, and $*$ denote significance at $1 \%, 5 \%$, and $10 \%$ levels, respectively. Robust standard errors were used. The dependent variable is the current account balance-to-GDP ratio.

Finally, the impact of non-commodity based SWFs on the current account volatility "instability" has been investigated, the fitted values (SWFFitted) calculated after running the regression model presented by table (10) have been used as an instrument to run the Arellano- Bond dynamic panel regression model represented by table 
(12). Empirical findings revealed that there might be a limited room for non-commodity based SWFs to promote the stability of the current account balance in the long run, as the coefficient on (SWFFitted) variable is not statistically significant. Instability episodes in the current account balances seemed to be persistent to a considerable extent as represented by the coefficient on the lagged dependent variable. Moreover, positive output gaps are expected to play a crucial role in curbing the volatility of the current account balance through the expansion of exports, meanwhile, government fiscal surpluses are expected to reduce the volatility of the current account balance, which corroborates the twin deficits hypothesis. On the other hand, real exchange rate appreciation could exacerbate the volatility of the current account balance due to its detrimental effect on the competitiveness of exports.

Table (12): The Determinants of the Current Account Instability

\begin{tabular}{|c|c|}
\hline Dependent Variable: CAInstability & Coefficient \\
\hline CAInstability (-1) & $0.5998496^{* * *}$ \\
\hline Trade Openness & 0.1819493 \\
\hline GDP Gap & $-0.4087463^{* *}$ \\
\hline Inflation & 0.0116883 \\
\hline Fiscal Balance & $-0.0417096^{* *}$ \\
\hline Financial Openness & 0.6611873 \\
\hline Age Dependency Ratio & -0.0383016 \\
\hline Log (REER) & $83.63728^{*}$ \\
\hline World Oil Price & -0.2089244 \\
\hline World Food Prices & 0.1254147 \\
\hline SWFFitted & -3.561676 \\
\hline Observations & 1225 \\
\hline Countries & 91 \\
\hline Instruments & 130 \\
\hline Arellano Bond Serial Correlation Test AR(2) \\
(P.value)
\end{tabular}

Notes: Symbols $* * *, * *$, and $*$ denote significance at $1 \%, 5 \%$, and $10 \%$ levels, respectively. Robust standard errors were used. The dependent variable is a three-year rolling window variation coefficient of the current account balance-to- GDP ratio to proxy for the current account instability.

\section{4- Conclusion:}

SWFs are state-owned investment vehicles with numerous types, objectives and investment strategies. These institutions are not a new phenomenon in the global economy as the beginning of their inception dates back to the pre-1970s. Moreover, they are currently playing an important role in both the MENA region and the global economy as their assets are estimated at over US\$7 trillion in June 2017, meanwhile, the GCC funds hold around 38.8 percent of these assets.

The IMF (2008) confirmed that SWFs can have potential effects on at least four areas of interest, which are fiscal policy, monetary policy, Public Sector Balance Sheet Implications and the External Stability. As for the external stability, SWFs may have important implications for the assessment of the economy's external stability both in the current and capital account, which is relevant for both the surveillance of countries with SWFs and for countries that receive large SWF inflows. Commodity exporting economies may run transitory current account surpluses during the period in which the resources are being extracted and exported, and to draw down the assets after the resources have been exhausted. Meanwhile, countries that receive SWF inflows are likely to be affected in terms of the capital and financial account, and relative prices, and accordingly external stability may be affected.

Empirical studies have mainly focused on investigating the role of sovereign wealth funds in promoting fiscal stability. To the best of our knowledge, no empirical studies have investigated the role of SWFs in promoting the external stability of the home economy, that's why this paper tried to fill this gap in the literature by employing econometric techniques to test this hypothesis.

Arellano- Bond dynamic panel data models were employed to assess the treatment effect of SWFs on both the level of current account balance and its volatility "instability" in countries that have established such investment vehicles, 
then we replicated the analysis for both commodity and non-commodity based SWFs to ensure that this effect is robust for different types of SWFs.

The main findings of our empirical analysis could be summarized as follows:

- Resource-rich economies, as well as countries with concentrated export baskets, are more likely to implement SWFs, also the GCC economies are more likely to prefer establishing these institutions. These findings were robust even when running separate models for both commodity and non-commodity based SWFs. The GCC economies are more likely to prefer establishing non-commodity based SWFs, which may be in order to maximize the return on their fiscal surpluses, which is actually the case for the United Arab Emirates.

- SWFs can play an important role in smoothing the management of the current account balance in the long run; also current account balances for the economies considered seemed to be persistent to a considerable extent in the long run. These findings were robust even when running separate regression models for both commodity and non-commodity based SWFs. Nonetheless, commodity-based SWFs are expected to outperform non-commodity based SWFs in terms of their ability to smooth the current account balance in the long run through the influx of returns on investments abroad which can partially offset temporary deficit in the trade balances for commodity-exporting economies in case of low world prices for oil and other commodities.

- Both the business cycle "GDP gap" and world oil prices can have a positive effect on the current account balance which is expected for oil exporting economies. On the other hand, openness to trade, real exchange rate appreciation, and world food prices are expected to have a negative effect on the current account balance in the long run, which is intuitive.

- SWFs can play a crucial role in promoting the stability of the current account balance in the long run, especially as instability episodes in the current account balances of the economies considered seemed to be persistent to some extent.

- Positive output gaps are expected to curb the volatility of the current account balance through the expansion of exports. On the other hand, both openness to trade and real exchange rate appreciation could exacerbate the volatility of the current account balance due to their detrimental effect on exports.

- The regression analysis for the role of commodity-based SWFs revealed that demographic factors "age dependency ratio" can limit the fluctuations in the current account balance in the long run, which may be because the increase in numbers of economically dependents in the economy is expected to limit consumption and stabilize imports in the long term.

- The regression analysis for the role of non-commodity based SWFs confirmed that government fiscal surpluses are expected to reduce the volatility of the current account balance in the long run, which corroborates the twin deficits hypothesis.

Our policy recommendation is that emerging economies should consider the establishment of SWFs as an important sovereign institution that would enable them to enhance the external stability of their home economies and dampen the fluctuations in their external balances through the influx of returns on financial investments abroad, as well as the allocation of privatization proceeds to theses investment vehicles to maximize the return on them and protect the rights of future generations in benefiting from them rather than directing such proceeds to finance current government expenditure and budget deficit. Finally, attention should be paid to the implementation of the generally accepted principles and practices when establishing SWFs to ensure their ability to work properly.

\section{References:}

[1]. Al-Hassan, A., Papaioannou,M., Skancke,M., and Cheng Chih Sung, (2013) "Sovereign Wealth Funds: Aspects of Governance Structures and Investment Management", IMF Working Paper No. 13/ 231.

[2]. Arellano, M., and Stephen Bond, (1991) "Some tests of specification for panel data: Monte Carlo evidence and an application to employment equations." The review of economic studies 58.2 (1991): pp.277-297.

[3]. Arellano, M., and Olympia Bover, (1995) "Another look at the instrumental variable estimation of errorcomponents models." Journal of econometrics 68.1 (1995): pp.29-51.

[4]. Blundell, R., and Stephen Bond, (1998) "Initial conditions and moment restrictions in dynamic panel data models." Journal of econometrics 87.1 (1998): pp.115-143.

[5]. Chinn, M. and E. Prasad, (2003) "Medium-Term Determinants of Current Accounts in Industrial and Developing Countries: An Empirical Exploration,” Journal of International Economics, Vol. 59 No. 1, pp. 47-76. 
[6]. Chinn, Menzie D. and Hiro Ito, (2006) "What Matters for Financial Development? Capital Controls, Institutions, and Interactions," Journal of Development Economics, Volume 81, Issue 1, pp.163-192 (October).

[7]. Clausen, J., and Kandil, M.,(2005) "On Cyclicality in the Current and Financial Accounts: Evidence from Nine Industrial Countries", IMF Working Paper No. 05/56.

[8]. Clower, E., and Hiro Ito, (2012) "The Persistence of Current Account Balances and its Determinants: The Implications for Global Rebalancing”, Asian Development Bank Institute Working Paper No. 400.

[9]. Coutinho, L., D. Georgiou, M. Heracleous, A. Michaelides, and S. Tsani, (2013) "Limiting Fiscal Procyclicality: Evidence from Resource-Rich Countries", Centre for Economic Policy Research Working Paper DP9672.

[10]. Debelle, G. and H. Faruqee, (1996) "What Determines the Current Account? A Cross- Sectional and Panel Approach," IMF Working Paper No. 96/58.

[11]. Elbadawi, I., Soto, R., and Hoda Youssef, (2018) "SOVEREIGN WEALTH FUNDS AND MACROECONOMIC STABILIZATION IN THE HOME ECONOMY", Economic Research Forum Working Paper No. 1175.

[12]. Fasano, U., (2000) "Review of the Experience with Oil Stabilization and Savings Funds in Selected Countries." IMF Working Paper No. 00/112.

[13]. Gomes, T., (2008) "The Impact of Sovereign Wealth Funds on International Financial Stability", Bank of Canada, Discussion Paper No. 2008-14.

[14]. Im, K., M. Pesaran, and Y. Shin, (2003) "Testing for Unit Roots in Heterogeneous Panels," Journal of Econometrics, Vol. 115, pp. 53-74.

[15]. IMF, (2008) "Sovereign Wealth Funds-A Work Program". Report prepared by the Monetary and Capital Markets and Policy Development Review Departments, International Monetary Fund, Washington, DC.IMF (2017): "Fiscal Rules Dataset, 1985-2015”, Fiscal Affairs Department, International Monetary Fund.

[16]. International Working Group of Sovereign Wealth Funds, (2008) "Sovereign Wealth Funds Generally Accepted Principles and Practices (Santiago Principles)".

[17]. Koh, W. C., (2016) "Fiscal Policy in Oil-exporting Countries: The Roles of Oil Funds and Institutional Quality", Review of Development Economics.

[18]. Krugman, P. and Obstfeld, M., 2003, “The International Monetary System, 1870-197”. Chapter 18, International Economics: Theory and Policy, Sixth Edition.

[19]. Lee, J., G. M. Milesi-Ferretti, J. Ostry, A. Prati, and L. A. Ricci, (2008) "Exchange Rate Assessments: CGER Methodologies", IMF Occasional Paper No. 261.

[20]. Levin, A., C-F. Lin, and C-S. Chu, (2002) "Unit Root Tests in Panel Data: Asymptotic and Finite-Sample Properties," Journal of Econometrics, Vol. 108, pp. 1-24.

[21]. Mohaddes, K. and H. Pesaran, (2017) "Oil prices and the global economy: Is it different this time around?", Energy Economics, Vol. 65, June, pp.315-325.

[22]. Morsy, H., (2009) "Current Account Determinants for Oil-Exporting Countries”, IMF Working Paper No. 09/28.

[23]. Nickell, Stephen J., (1981) "Biases in Dynamic Models with Fixed Effects." Econometrica 49.6 (1981): pp. 1417-26.

[24]. Salvatore, D, 1999,“Open-Economy Macroeconomics: Adjustment Policies”, Chapter 18. International Economics, Sixth Edition.

[25]. Sovereign Wealth Funds Institute, (2017), SWFI Online Database.

[26]. Sugawara, N., (2014) "From Volatility to Stability in Expenditure: Stabilization Funds in Resource-Rich Countries", IMF Working Paper No.14/43.

Osama El-Baz works as an Economist at Ashaqia Chamber of Commerce in Ad-Dammam, Saudi Arabia. El-Baz earned a Master's degree in Economics with an excellent grade from the Faculty of Economics and Political Science, Cairo University, Egypt. He is an experienced Economist whose research papers have been published in peer-reviewed Journals. He has held positions at both public entities and NGOs. His research interests lie in the areas of Macroeconomics, International Economics, International Finance, and Applied Econometrics. El-Baz may be reached at osamaeces@ gmail.com 


\section{Annexure}

Table (1): Variables used in Regression Analysis

\begin{tabular}{|c|c|c|}
\hline Variable & Description & Source \\
\hline CA & $\begin{array}{l}\text { Current account balance-to-GDP } \\
\text { ratio }\end{array}$ & $\begin{array}{l}\text { World Bank, World Development } \\
\text { Indicators }\end{array}$ \\
\hline CAInstability & $\begin{array}{l}\text { A three-year rolling window } \\
\text { variation coefficient of the } \\
\text { current account balance-to- GDP } \\
\text { ratio is used to proxy for the } \\
\text { current account instability }\end{array}$ & $\begin{array}{l}\text { World Bank, World Development } \\
\text { Indicators }\end{array}$ \\
\hline Resource Rent Cycle & $\begin{array}{l}\text { The cyclical component of } \\
\text { natural resource rents-to-GDP } \\
\text { ratio is calculated using the } \\
\text { Hodrick Prescott filter. }\end{array}$ & $\begin{array}{l}\text { World Bank, World Development } \\
\text { Indicators }\end{array}$ \\
\hline Revenue Instability & $\begin{array}{c}\text { A three-year rolling window } \\
\text { variation coefficient of general } \\
\text { government revenue (\% of GDP) } \\
\text { is used to proxy for the instability } \\
\text { of government revenues }\end{array}$ & $\begin{array}{l}\text { World Bank, World Development } \\
\text { Indicators }\end{array}$ \\
\hline Inflation & CPI $(2010=100)$ & $\begin{array}{l}\text { World Bank, World Development } \\
\text { Indicators }\end{array}$ \\
\hline Economic Development & $\begin{array}{l}\text { GDP per capita annual growth } \\
\text { rates }\end{array}$ & $\begin{array}{l}\text { World Bank, World Development } \\
\text { Indicators }\end{array}$ \\
\hline Export Concentration & Export Concentration Index & UNCTAD Statistics \\
\hline GCC & $\begin{array}{c}\text { A zero- one dummy variable that } \\
\text { takes one for GCC economies } \\
\text { and zero otherwise }\end{array}$ & \\
\hline Trade Openness & $\begin{array}{l}\text { It is the sum of exports and } \\
\text { imports divided by GDP }\end{array}$ & $\begin{array}{l}\text { World Bank, World Development } \\
\text { Indicators }\end{array}$ \\
\hline SWF & $\begin{array}{l}\text { A zero- one dummy variable that } \\
\text { takes one in case of having an } \\
\text { SWF in place and zero otherwise }\end{array}$ & $\begin{array}{l}\text { Sovereign Wealth Funds Institute } \\
\qquad(2017)\end{array}$ \\
\hline GDP Gap & $\begin{array}{l}\text { Output gap is used as a proxy for } \\
\text { the business cycle fluctuations. It } \\
\text { is calculated as the relative } \\
\text { deviation of actual output from its } \\
\text { trend using the Hodrick Prescott } \\
\text { filter }\end{array}$ & $\begin{array}{l}\text { World Bank, World Development } \\
\text { Indicators }\end{array}$ \\
\hline Fiscal Balance & $\begin{array}{l}\text { General government net } \\
\text { lending/borrowing-to-GDP ratio }\end{array}$ & IMF, World Economic Outlook \\
\hline Financial Openness & $\begin{array}{l}\text { Chinn-Ito Index, Kaopen index is } \\
\text { used }\end{array}$ & $\begin{array}{l}\text { Chinn, Menzie D. and Hiro Ito } \\
\text { (2006) }\end{array}$ \\
\hline Age Dependency Ratio & $\begin{array}{c}\text { Young (\%) of working-age } \\
\text { population. It is the ratio of } \\
\text { younger dependents who are } \\
\text { younger than } 15 \text { to the working- } \\
\text { age population whose ages are } \\
\text { between (15-64) }\end{array}$ & $\begin{array}{l}\text { World Bank, World Development } \\
\text { Indicators }\end{array}$ \\
\hline
\end{tabular}




\begin{tabular}{|c|c|c|}
\hline Log (REER) & $\begin{array}{c}\text { The natural logarithm of real } \\
\text { effective exchange rate }\end{array}$ & $\begin{array}{c}\text { World Bank, World Development } \\
\text { Indicators }\end{array}$ \\
\hline World Oil Price & $\begin{array}{c}\text { Nominal world oil prices in U.S.\$ } \\
\text { per barrel (OPEC Basket) }\end{array}$ & $\begin{array}{c}\text { Saudi Arabia Monetary } \\
\text { Authority, Annual Statistics } \\
(2016)\end{array}$ \\
\hline World Food Prices & FAO Food Price Index & FAO (2017) \\
\hline
\end{tabular}

Table (2): List of Countries used in Regression Analysis

\begin{tabular}{|c|c|c|c|c|c|}
\hline Albania & Congo, Dem. Rep. & $\begin{array}{c}\text { Hong Kong SAR, } \\
\text { China* }\end{array}$ & Madagascar & Peru* & Trinidad and Tobago* \\
\hline Algeria* & Costa Rica & Hungary & Malaysia* & Philippines & Tunisia \\
\hline Argentina & Croatia & Iceland & Mali & Poland & Turkey \\
\hline Armenia & Czech Republic & India & Mauritania* & Portugal & United Arab Emirates* \\
\hline Australia* & Denmark & Indonesia* & Mexico & Qatar* & United States \\
\hline Azerbaijan* & Dominican Republic & Iran, Islamic Rep.* & Moldova & Romania & United Kingdom \\
\hline Bahrain* & Ecuador & Ireland* & Morocco & Russian Federation* & \\
\hline Bangladesh & Egypt & Israel & Mozambique & Saudi Arabia* & \\
\hline Belarus & El Salvador & Italy* & Namibia & Senegal* & \\
\hline Bolivia* & Ethiopia & Jamaica & Netherlands & Singapore* & \\
\hline Botswana* & France* & Japan & New Zealand & Slovenia & \\
\hline Brazil* & Gabon & Jordan & Nicaragua & South Africa & \\
\hline Bulgaria & Gambia, The & Kazakhstan* & Niger & Spain & \\
\hline Burkina Faso & Germany & Kenya & Nigeria & Sri Lanka & \\
\hline Cameroon & Ghana & Korea, Rep.* & Norway* & Suriname & \\
\hline Canada & Greece & Kuwait* & Oman* & Sweden & \\
\hline Chile* & Guatemala & Latvia & Pakistan & Switzerland & \\
\hline China* & Guinea & Lebanon & Panama* & Tanzania & \\
\hline Colombia & Guinea-Bissau & Lithuania & Papua New Guinea & Thailand & \\
\hline Congo, Rep. & Honduras & Libya* & Paraguay & Togo & \\
\hline
\end{tabular}

Note: $\left({ }^{*}\right)$ country with one or more Sovereign Wealth Fund. 
Table (3): List of Countries used in Regression Analysis, With Commodity vs Non-commodity based SWFs and Years of Inception

\begin{tabular}{|c|c|c|}
\hline Country & Commodity & Non-Commodity \\
\hline Algeria & 2000 & - \\
\hline Australia & 2012 & 2006 \\
\hline Azerbaijan & 1999 & - \\
\hline Bahrain & - & 2006 \\
\hline Bolivia & - & 2012 \\
\hline Botswana & 1994 & - \\
\hline Brazil & - & 2008 \\
\hline Chile & 2006 & - \\
\hline China & - & 1997 \\
\hline France & - & 2008 \\
\hline Hong Kong & - & 1993 \\
\hline Indonesia & - & 2006 \\
\hline Iran, Islamic Rep. & 2011 & - \\
\hline Ireland & - & 2001 \\
\hline Italy & - & 2011 \\
\hline Kazakhstan & 2000 & 2008 \\
\hline Korea, Rep. & - & 2005 \\
\hline Kuwait & 1953 & - \\
\hline Libya & 2006 & - \\
\hline Malaysia & - & 1993 \\
\hline Mauritania & 2006 & - \\
\hline Norway & 1990 & - \\
\hline Oman & 1980 & - \\
\hline Panama & - & 2012 \\
\hline Peru & - & 1999 \\
\hline Qatar & 2005 & - \\
\hline Russian Federation & 2008 & 2011 \\
\hline Saudi Arabia & 1952 & - \\
\hline Senegal & - & 2012 \\
\hline Singapore & - & 1974 \\
\hline Trinidad and Tobago & 2000 & - \\
\hline United Arab Emirates & 1976 & 2006 \\
\hline
\end{tabular}

Source: Sovereign Wealth Funds Institute, (2017), SWFI Online Database. 